\title{
INCORPORATING PINEAPPLE PEEL EXTRACT INTO CHITOSAN COATING FOR RETAINING POSTHARVEST QUALITY OF WHITE SHRIMP (Litopaeneus vannamei)
}

\author{
MAISARAH SHAMSULKAMAL ${ }^{\mathrm{A}}$, WAN ZAWIAH WAN ABDULLAH ${ }^{\mathrm{B}}$ AND AIDILLA \\ MUBARAK ${ }^{\mathrm{C}, \mathrm{D}^{*}}$
}

${ }^{1,2,3}$ Faculty of Fisheries and Food Science, Universiti Malaysia Terengganu, 21030 Kuala Nerus, Terengganu, Malaysia. ${ }^{4}$ Institute of Tropical Aquaculture and Fisheries, Universiti Malaysia Terengganu, 21030 Kuala Nerus, Terengganu, Malaysia.

\begin{abstract}
This study explored the effect of chitosan coating incorporated with pineapple peel extract on the postharvest quality of white shrimp (Litopenaeus vannamei) during nine days of storage at $5^{\circ} \mathrm{C}$. Incorporation of pineapple peel extract in chitosan coating was able to delay the decline of some important postharvest quality measures of white shrimp which includes reduced formation of total volatile basic nitrogen and peroxide value. It also decreased melanosis formation and hindered growth of Pseudomonas which assists in prolonging shelf ife quality of white shrimp. Additionally, shrimp coated with chitosan incorporated with pineapple peel extract had an improved sensory score which includes assessment on overall acceptance. The results showed that chitosan coating incorporated with pineapple peel extract could be a natural approach towards retaining postharvest quality of shrimp as well as decrease the employment of synthetic treatments. The utilization of pineapple peel could also reduce the agricultural waste in the environment.
\end{abstract}

Keywords: Food quality, pineapple peel, agricultural waste, postharvest, antioxidant, phenolics.

\section{Introduction}

White shrimp is one of the foremost valuable crustaceans representing $15.4 \%$ of the total value of international traded fish products in 2008 (FAO, 2010). However, shrimp is a very perishable product in which the post-mortem changes lead to postharvest losses (Hsu et al., 2017). White shrimp (Litopenaeus vannamei) is highly perishable and has a limited shelf life ( $\mathrm{Na}$ et al., 2018). Lipid oxidation easily occurs in shrimp due to the large concentration of lipid in shrimp flesh (Sriket et al., 2007). After harvest, quality of shrimp declines due to biochemical activity (Boonsumrej et al., 2007) and microbiological activity from the presence of spoilage bacteria such as Pseudomonas spp (Bono \& Badalucco, 2012). Acceptability also reduced with the unfavourable colour change related to melanosis on the surface of white shrimp. Melanosis or blackspot is a natural postmortem process that involves polymerization of phenols into insoluble black pigments (melanin) by polyphenol oxidase followed by non-enzymatic polymerization of the quinones (Nirmal \& Benjakul, 2011). To avoid this problem, various techniques, such as application of edible coating and plant extracts, have been suggested to prolong the shelf life of white shrimp thus reducing postharvest losses.

Pineapple peel is derived from the byproduct of pineapple processing (Ruslan et al., 2017). Ahmad and Sharma (2012) reported that pineapple extract contained chlorogenic acid and ferulic acid with beneficial antioxidant activity. The antioxidant property can be beneficial to retain postharvest quality of white shrimp where it can potentially reduce lipid oxidation activity in the flesh of shrimp. However, the potential of this agricultural waste as an agent to reduce deterioration of white shrimp has not been previously reported. Therefore, the aim of this study was to assess the effect of pineapple peel extract combined with chitosan coating on the postharvest quality of white shrimp (Litopenaeus vannamei) during nine days of storage at $5^{\circ} \mathrm{C}$. 


\section{Materials and Methods}

\section{Preparation of Pineapple Peel Waste Extract and Coating Material}

Pineapple peels were obtained from fresh pineapple fruits and dried at $50^{\circ} \mathrm{C}$ and ground into powder using rock grinder with $250 \mu \mathrm{m}$ particle size. Pineapple peel powder was percolated with methanol at room temperature for three days and filtered. The residue was re-extracted and filtrates were combined and evaporated to dryness by using rotary evaporator (Ahmed et al., 2011; Zayed et al., 2014). Chitosan coating solution was added with different concentrations of pineapple peel extract ( $4 \%$ and $8 \%$ ).

\section{Shrimp Collection and Treatments}

Fresh white shrimp (Litopenaeus vannamei) of uniform size was purchased from a local market in Kuala Terengganu. The white shrimp was kept cold and transported immediately to postharvest laboratory in Universiti Malaysia Terengganu and assigned to four treatment groups:

1. Control: uncoated white shrimp

2. Chitosan: chitosan coating only without incorporation of pineapple peel extract

3. Chitosan $+4 \%$ PP extract: chitosan coating with incorporation of $4 \%$ pineapple peel extract

4. Chitosan $+8 \%$ PP extract: chitosan coating with incorporation of $8 \%$ pineapple peel extract

The assigned shrimp samples were immersed in the respective coating solutions for three minutes to achieve uniform surface coating, and then drained and dried at room temperature, prior being packed in polyethylene bags and stored at $5^{\circ} \mathrm{C}$ for nine days (Souza et al., 2010). Postharvest quality assessments were performed at days $0,3,6$ and 9 of the experiment.

\section{Weight Loss}

Weight loss of shrimp from each treatment was measured throughout the days of storage period at every three-day interval. The difference between initial and final weights was considered as the total weight loss during the storage interval and was expressed as percentage weight loss using the following equation:

Percentage weight loss $=\frac{\text { Initial weight }- \text { Final weight }}{\text { Initial weight }}$

\section{Texture Analysis}

Texture was assessed using the TA.XT Plus Texture Analyzer Stable Micro System (Texture Exponent 32 Version 4.0.9.0, Surrey, United Kingdom) fitted with a cylindrical compression probe of radius $36 \mathrm{~mm}$. The shrimps with shells on were compressed on their sides to approximately $50 \%$ of the sample's width to avoid cracking, with pre-test speed of 2.0 $\mathrm{mm} / \mathrm{s}$, test speed of $2.0 \mathrm{~mm} / \mathrm{s}$, post-test speed of $2.0 \mathrm{~mm} / \mathrm{s}$ and trigger force of $5 \mathrm{~g}$. Data was collected for hardness, springiness and resilience (Balfour, 2014).

\section{Colour Analysis}

Colour of the shrimp was taken using a chromameter (Model CR-400, Konika Minolta) to determine the shrimp's colour at three different points (head, body and tail) and reading of $\mathrm{L}^{*}$ and $\mathrm{b}^{*}$ were recorded (Yuan et al., 2016).

\section{pH, Total Volatile Base Nitrogen (TVB-N) and Peroxide Value}

$\mathrm{pH}$ was measured using a $\mathrm{pH}$ meter (EcoScan $\mathrm{pH} 5$, EUTECH Instrument) on a mixture of 5 $\mathrm{g}$ of shrimp flesh in $20 \mathrm{ml}$ distilled water (Imran et al., 2013).

TVB-N was determined according to Sun et al. (2014) using steam distillation of trichloroacetic acid with an automatic Kjeldahl apparatus (Kjeltec-8400, Foss, Sweden). The TVB-N values were expressed as $\mathrm{mg} \mathrm{N} / 100 \mathrm{~g}$ shrimp meat.

Peroxide value was carried out using method by Rahman et al. (2002) and expressed as $\mathrm{g} / \mathrm{fat}$. 


\section{Microbial Quality Evaluation}

Total plate counts (TPC) and Pseudomonas was determined by preparing serial dilutions of homogenized shrimp and plated on nutrient agar (NA) for TPC and PSA for Pseudomonas using spread plate method. The plates were incubated at $36^{\circ} \mathrm{C}$ for NA and at $30^{\circ} \mathrm{C}$ for PSA ( 24 to 48 hours). Results were expressed as $\log _{10} \mathrm{CFU} /$ $\mathrm{mL}$.

\section{Sensory Analysis and Evaluation of Melanosis}

The sensory analysis was performed on raw shrimp using overall acceptance test with five point hedonic scale. The melanosis assessment was assessed through visual observation using ten-point scoring according to Montero et al. (2001) as follows:

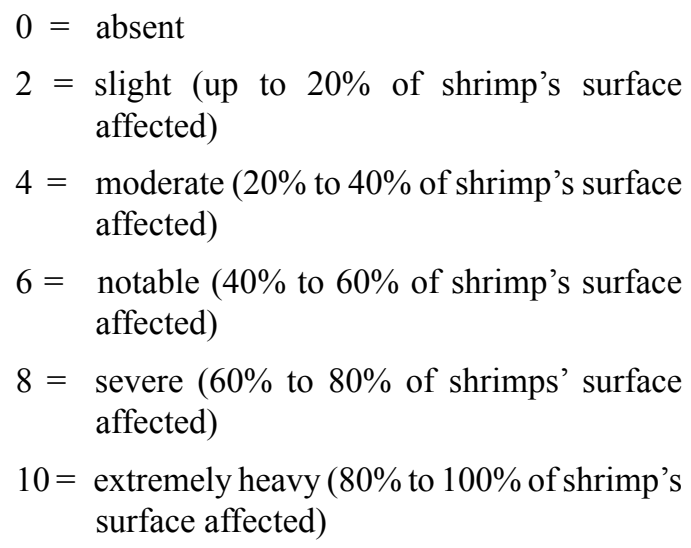
affected)

$4=$ moderate $(20 \%$ to $40 \%$ of shrimp's surface affected)

$6=$ notable $(40 \%$ to $60 \%$ of shrimp's surface affected)

$8=$ severe $(60 \%$ to $80 \%$ of shrimps' surface affected)

$10=$ extremely heavy $(80 \%$ to $100 \%$ of shrimp's surface affected)

\section{Statistical Analysis}

A completely randomized experimental design was performed with three replicates per treatment. Data were subjected to analysis of variance (ANOVA) followed by Tukey's HSD for multiple comparison test using IBM SPSS Statistics 24. Statistical significance is considered at $\mathrm{p}<0.05$.

\section{Results and Discussion}

\section{Weight Loss}

Percentage of weight loss for shrimp coated with chitosan, chitosan $+4 \%$ PP extract and chitosan $+8 \%$ PP extract were found to be higher than control (uncoated) shrimp $(\mathrm{p}<0.05)$ (Figure 1). This indicated that pineapple peel extract was not effective in delaying weight loss in shrimp during storage at $5^{\circ} \mathrm{C}$ for a period of nine days. This might be due to the bromelain enzyme contained in the pineapple peel (Schieber et al., 2001). Martins et al. (2014) reported that bromelain is included in the hydrolase classification and specifically from the group of cysteine proteinase, known for the ability of breaking peptide bonds, separation of proteins and amino acids. However, utilizing potential benefit from the antioxidative activity of other bioactive compounds in this agricultural waste is perhaps possible with removal of bromelain prior to incorporation in coating solutions. This is possibly achievable using purification methods reported in Soares et al. (2012).

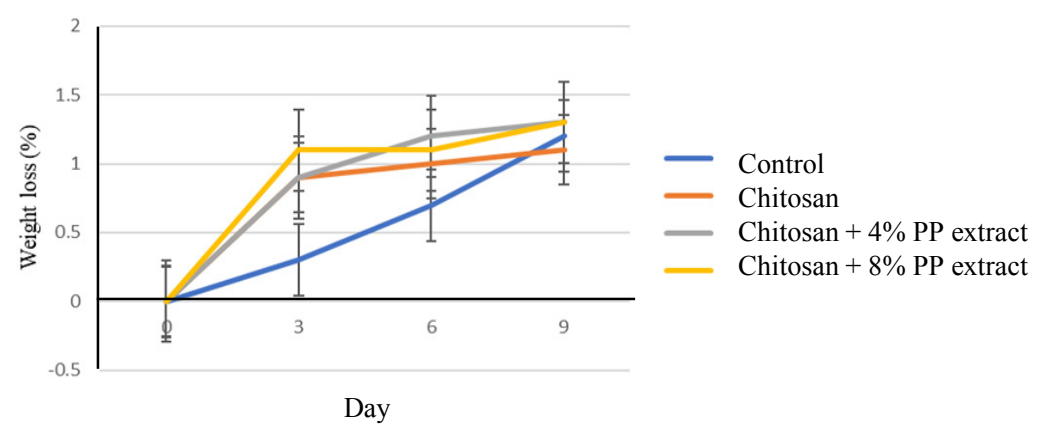

Figure 1: The effects of chitosan and pineapple peel extract coating on percentage of weight loss in white shrimp stored at $5^{\circ} \mathrm{C}$ for nine days. Data presented as mean \pm standard deviation 


\section{Texture}

One of the important parameters for consumer acceptability is texture (Farajzadeh et al., 2016). Figure 2 illustrates the hardness, resilience and springiness of uncoated and coated shrimp. There was a gradual increase in hardness for all shrimps throughout the storage period. The increase of hardness during storage is possibly due to accumulation and loss of water (Bindu et al., 2013). Resilience parameter in this analysis refers to the ability of the shrimp to elastically recover after being subjected to speed and force (Meinert et al., 1999). The variation of springiness is due to the activity of autolytic enzyme (ATPase and cathepsins) collapsing the connective tissue and myofibrillar protein hydrolyzed (Godiksen et al., 2009). In this study, no significant impact was observed from all coating treatments of chitosan and PP extracts $(p>0.05)$. There is a tendency for slightly lower value of hardness, springiness and resilience in shrimp coated with chitosan $+8 \%$ PP extract compared to control and other coating treatments, but the differences were not significant. This observation could be due to the hydrolysis of protein as a result from higher bromelain contained in the PP extract, which supports the observation of higher weight loss of shrimp coated with the extract.

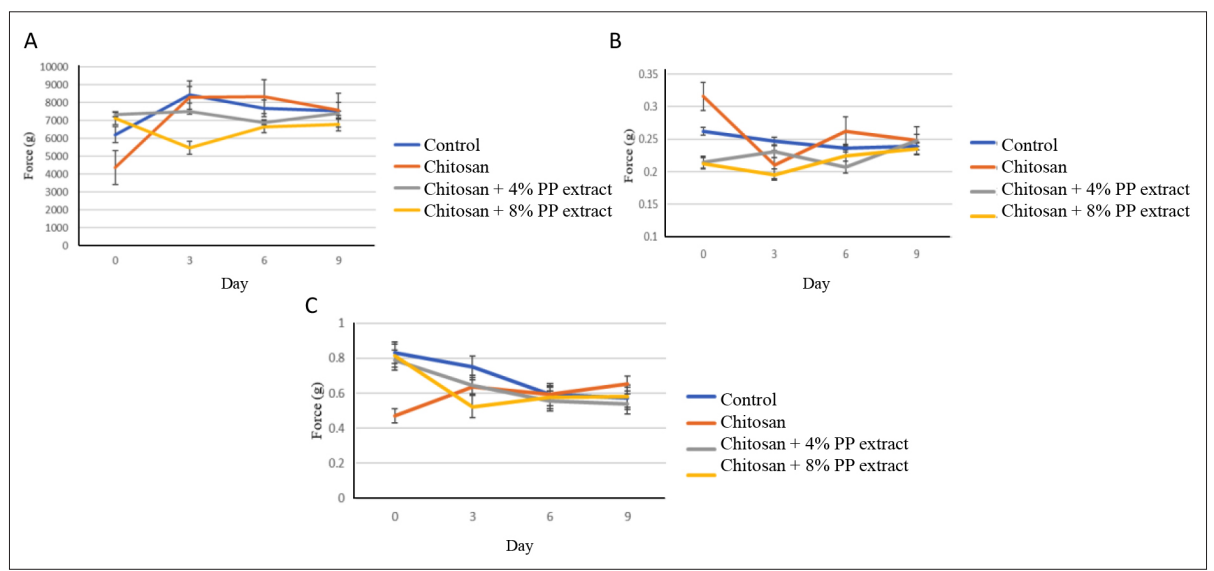

Figure 2: The effects of chitosan and pineapple peel extract coating on (A) hardness, (B) resilience and (C) springiness of white shrimp stored at $5^{\circ} \mathrm{C}$ for nine days. Data is presented as mean \pm standard deviation

\section{Colour}

One of the crucial visual characteristics for seafood is colour (Farajzadeh et al., 2016). There was no significant impact of all treatments for both of the chromacity $L^{*}$ (lightness) and chromacity b* (yellowness) on shrimp $(\mathrm{p}>0.05)$ (Figure 3). However, there was a tendency for slightly higher increase in $b^{*}$ value of shrimp coated with chitosan, chitosan $+4 \%$ PP extract and chitosan $+8 \%$ PP extract during storage at $5^{\circ} \mathrm{C}$. The yellowish colour of chitosan and PP extract containing carotenoid could have a small impact on the yellowish appearance of coated shrimp (Ferreira et al., 2016). 


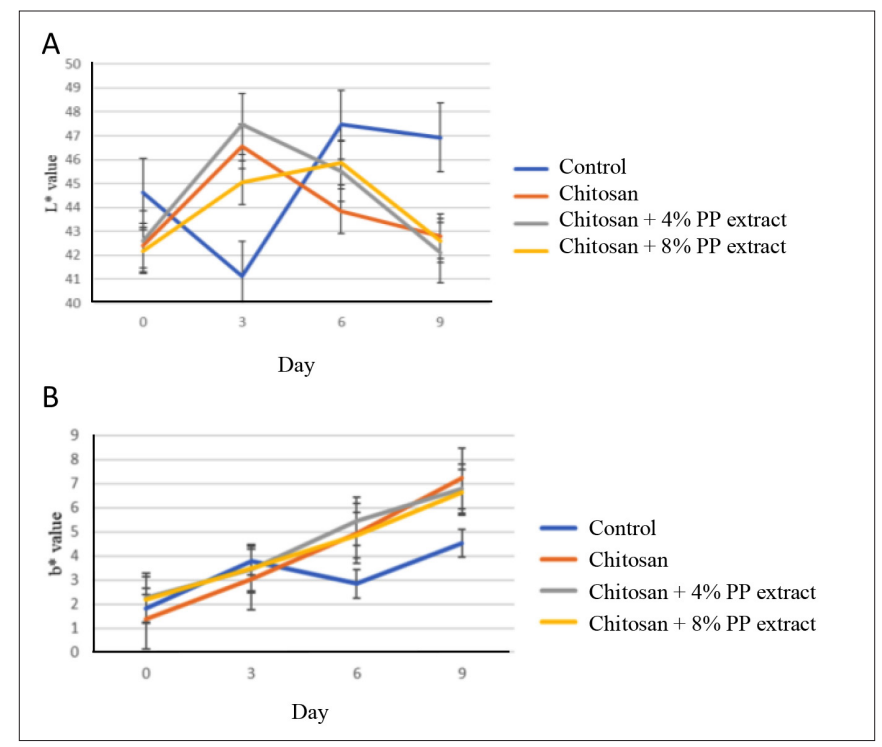

Figure 3: The effects of chitosan and pineapple peel extract coating on colour (A) $\mathrm{L}^{*}$ value and (B) $\mathrm{b}^{*}$ value in white shrimp stored at $5^{\circ} \mathrm{C}$ for nine days. Data is presented as mean \pm standard deviation

\section{pH, Total Volatile Base Nitrogen (TVB-N) and Peroxide Value}

$\mathrm{pH}$ greater than 7.6 for shrimp is subject to be rejected due to the classification as unacceptable or putrid (Nirmal \& Benjakul, 2011). Coating treatments in this study did not significantly affect the $\mathrm{pH}$ value of the white shrimps (Figure 4A). However, control (uncoated) shrimp showed a tendency for higher rise of $\mathrm{pH}$, but the recorded $\mathrm{pH}$ is still in the acceptable range. The slightly lower $\mathrm{pH}$ during storage period for shrimp coated with chitosan $+4 \%$ PP extract and chitosan $+8 \%$ PP extract is possibly due to acidic environment of coating solution that has been used for the treatment (Mohan et al., 2012). Drop of $\mathrm{pH}$ value could help in inhibition of microorganisms' growth which can help prolong the shelf life of the shrimp (Fan et al., 2009).

The rise of TVBN value in seafood is associated with microbial and chemical spoilage because TVBN measures the ammonia produced from the bacteria and protein breakdown products (Yuan et al., 2016). Chinese National Standard (GB2741-94) (2010) has set the safe limit to $<300 \mathrm{mg}$ TVBN/100g for marine products. In this study, it was observed that all coating treatments lower the formation of TVBN produced in spoilage of the shrimp when compared to control $(p<0.05)$. Lowest TVBN value was observed in shrimp coated with chitosan $+8 \%$ PP extract.

Peroxide value (PV) shows primary lipid oxidation concentration in products (Farajzadeh et al., 2016). The drop of PV on day nine of storage in shrimp coated with chitosan $+8 \%$ PP extract was possibly due to hydroperoxide decomposition in order to form short hydrocarbon chain such as aldehydes (Nirmal \& Benjakul, 2011). Other than that, the phenolic compound that is present in PP extract serves as antioxidant that could inhibit the lipid oxidation (Saraswaty et al., 2017). Chitosan coating with incorporation of $4 \%$ and $8 \%$ of PP extracts showed a low PV rate due to chitosan properties as it is a good barrier to oxygen (Jeon et al., 2002). 


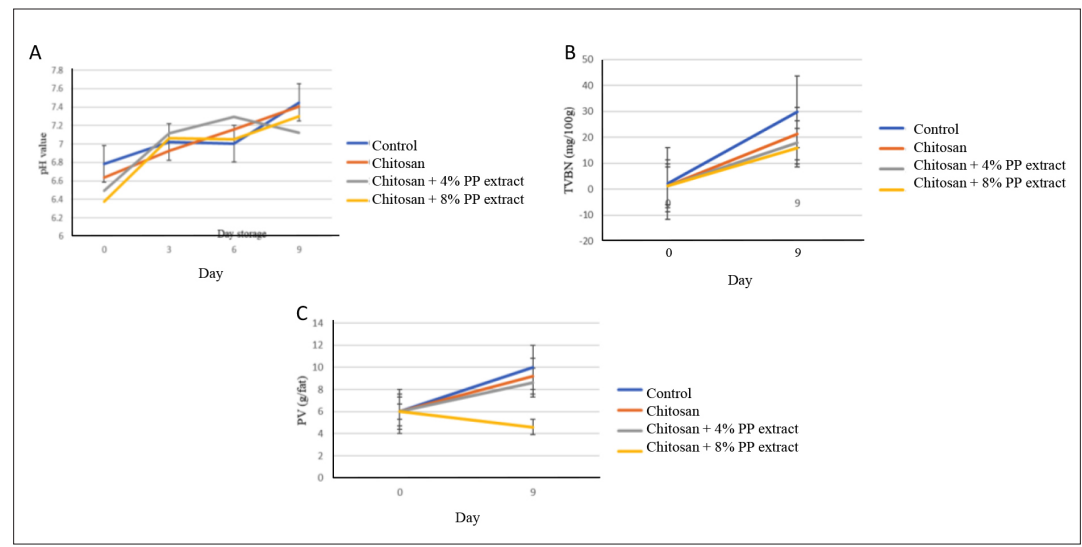

Figure 4: The effects of chitosan and pineapple peel extract coating on (A) $\mathrm{pH}$ value, (B) increase of TVBN from day 0 to day nine and (C) increase of peroxide value from day 0 to day 9 in white shrimp stored at $5^{\circ} \mathrm{C}$.

Data presented as mean \pm standard deviation

\section{Sensory Analysis}

Data gained from overall acceptance test is illustrated in Figure 5. Coated shrimps were more favourable to panels than control (uncoated) shrimps. Shrimp coated with chitosan $+8 \%$ PP extract scored the highest for all attributes, meanwhile control shrimp scored the lowest. Figure 6 shows the melanosis scoring on white shrimp stored for nine days at $5^{\circ} \mathrm{C}$. Shrimp coated with chitosan and chitosan with PP extracts were less prone to melanosis development compared to control (uncoated) shrimp. Chitosan has an oxygen barrier property (Huang et al., 2012) which may delay the development of melanosis. Shrimp coated with chitosan + PP extracts reduced melanosis formation better than shrimp coated with chitosan only $(\mathrm{p}<0.05)$. The melanosis is induced by polyphenol oxidase enzymatic action where it automatically oxidized the occurring phenols from amino acid to quinones (Arancibia et al., 2015). Phenolic compounds in the pineapple peel could be attributed to inhibiting the polyphenol oxidase and that resulted in reduced quinone formation in the white shrimp (Nirmal \& Benjakul, 2011). This is in agreement with previous studies which reported the efficiency of catechin, ferulic acid, and green tea extract on retaining quality of white shrimp (Nirmal \& Benjakul, 2011; Yuan et al., 2016).

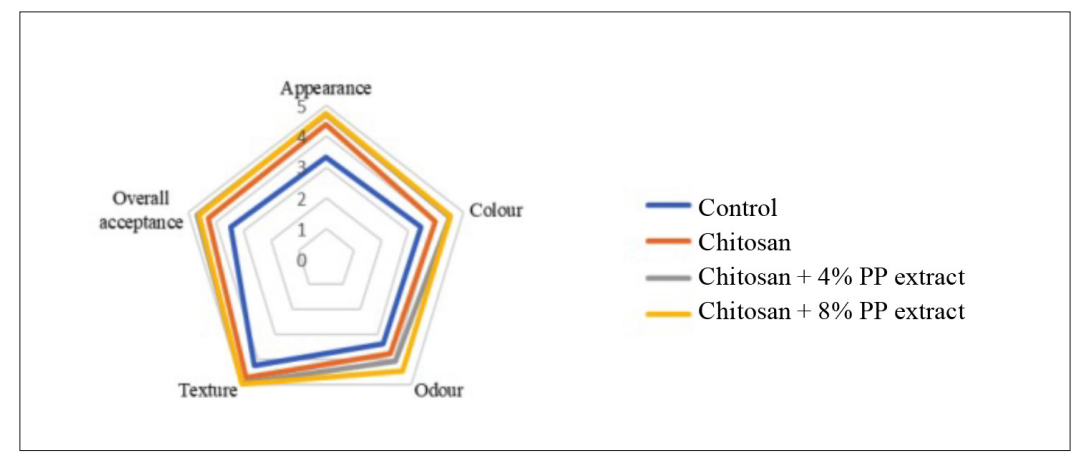

Figure 5: Overall acceptance of raw white shrimp stored at $5^{\circ} \mathrm{C}$ for nine days. Data is presented as mean \pm standard deviation 


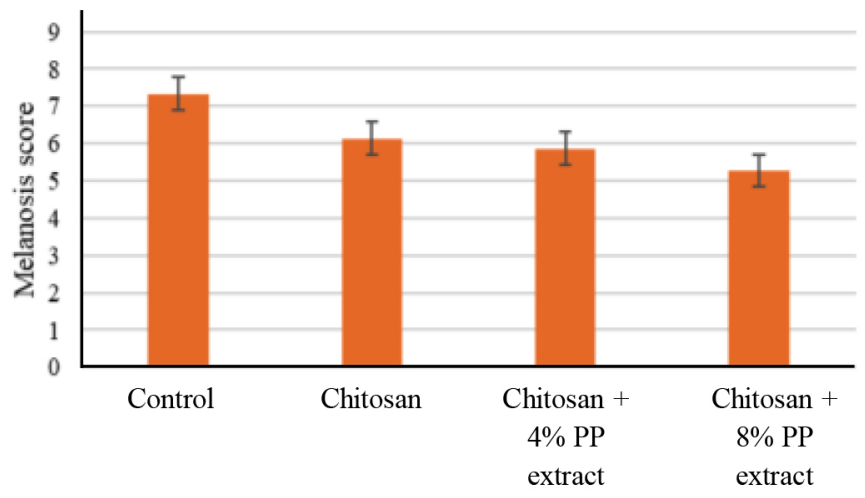

Figure 6: Melanosis assessment of white shrimp after nine days of storage at $5^{\circ} \mathrm{C}$. Data is presented as mean \pm standard deviation

\section{Microbial Quality Evaluation}

The microbial load in evaluated shrimp at day0 of experiment was found to be acceptable. After nine days of storage, all samples showed an increase in total plate count and number of Pseudomonas detected. There was no effect of coating treatments on improving the total plate count of white shrimp (Table 1). However, shrimp coated with chitosan $+4 \%$ PP extract and chitosan $+8 \%$ PP extract showed a lower Pseudomonas compared to control and shrimp coated with chitosan only (Table 2). Bromelain in pineapple has been reported for its antimicrobial activity (Loon et al., 2018). This proteolytic enzyme breaks down the protein of bacterial membrane and causes the bacteria cell death (Caesarita et al., 2011; Zharfan et al., 2017). The utmost group of microorganisms that resulted to spoilage in seafood is gram-negative psychrotrophic bacteria (Nirmal \& Benjakul, 2011) which includes Pseudomonas spp. (Chau et al., 2011). Phenols that are also found in pineapple peel (Ahmad \& Sharma, 2012) are lipophilic compounds which can attract lipid molecules in membrane cell, causing damage to the cell membrane of bacteria and subsequently break down the cell which will lead to cell death (Maurer, 2001; Loon et al., 2018).

Table 1: The effect of chitosan and pineapple peel extract coating on total plate count of white shrimp stored at $5^{\circ} \mathrm{C}$ for nine days

\begin{tabular}{lcc}
\hline \multirow{2}{*}{\multicolumn{1}{c}{ Treatment }} & \multicolumn{2}{c}{ Microbial Load $\left(\log _{10}\right.$ CFU $\left./ \mathbf{m L}\right)$} \\
\cline { 2 - 3 } & Day 0 & Day 9 \\
\hline Control & $<4.0 \mathrm{CFU} / \mathrm{mL}$ & $>2000 \mathrm{CFU} / \mathrm{mL}$ \\
Chitosan & $<4.0 \mathrm{CFU} / \mathrm{mL}$ & $>2000 \mathrm{CFU} / \mathrm{mL}$ \\
Chitosan $+4 \%$ PP extract & $<4.0 \mathrm{CFU} / \mathrm{mL}$ & $>2000 \mathrm{CFU} / \mathrm{mL}$ \\
Chitosan $+8 \%$ PP extract & $<4.0 \mathrm{CFU} / \mathrm{mL}$ & $>2000 \mathrm{CFU} / \mathrm{mL}$ \\
\hline
\end{tabular}


Table 2: The effect of chitosan and pineapple peel extract coating on Pseudomonas growth in white shrimp stored at $5^{\circ} \mathrm{C}$ for nine days

\begin{tabular}{lcc}
\hline \multirow{2}{*}{ Treatment } & \multicolumn{2}{c}{ Colony Forming Unit (cfu/ml) } \\
\cline { 2 - 3 } & \multicolumn{1}{c}{ Day 0 } & Day 9 \\
\hline Control & $<4.0 \mathrm{CFU} / \mathrm{mL}$ & $>2000 \mathrm{CFU} / \mathrm{mL}$ \\
Chitosan & $<4.0 \mathrm{CFU} / \mathrm{mL}$ & $>2000 \mathrm{CFU} / \mathrm{mL}$ \\
Chitosan $+4 \%$ PP extract & $<4.0 \mathrm{CFU} / \mathrm{mL}$ & $4.45 \mathrm{CFU} / \mathrm{mL}$ \\
Chitosan $+8 \%$ PP extract & $<4.0 \mathrm{CFU} / \mathrm{mL}$ & $4.45 \mathrm{CFU} / \mathrm{mL}$ \\
\hline
\end{tabular}

\section{Conclusion}

Chitosan incorporating pineapple peel extract as an edible coating was effective in retaining some important postharvest quality of white shrimp. Chitosan incorporated with $4 \%$ and $8 \%$ pineapple peel extract was able to significantly reduce the formation of total volatile basic nitrogen, peroxide value, formation of melanosis and growth of Pseudomonas. Overall acceptance test indicated that panelists preferred white shrimp that was coated with chitosan incorporated with $8 \%$ pineapple peel extract. Although the shrimps were classified as unacceptable for consumption at the end of 9 days of storage, the coating treatments were observed to be able to delay deterioration especially in reducing total volatile basic nitrogen and melanosis formation. Although positive implications were provided by the pineapple peel in chitosan coating, bromelain contained in this fruit peel possibly caused an enhanced weight loss of treated white shrimp. Therefore, removal of the bromelain enzyme could be considered as a valuable pretreatment prior to using the peel as coating agent in retaining quality of shrimp to fully utilize potential of this fruit waste. Utilizing such waste can be an alternative to chemical treatments for reducing postharvest losses of the shrimp, thus assisting in ensuring sufficient food supply from this protein source. Utilization of such fruit waste could also help in reducing agricultural waste.

\section{Acknowledgements}

The authors acknowledge the support from the Faculty of Fisheries and Food Science, Universiti Malaysia Terengganu and also thanks the staffs in the Postharvest Laboratory for the technical assistance given.

\section{References}

Ahmad, N., \& Sharma, S. (2012). Green synthesis of silver nanoparticles using extracts of Ananas comosus. Green and Sustainable Chemistry, 2(04), 141.

Ahmed, F., Rahman, S., Ahmed, N., Hossain, M., Biswas, A., Sarkar, S., \& Khatun, A. (2011). Evaluation of Neolamarckia cadamba (Roxb.) Bosser leaf extract on glucose tolerance in glucose-induced hyperglycemic mice. African Journal of Traditional, Complementary and Alternative Medicines, 8(1), 79-81.

Arancibia, M.Y., Lopez-Caballero, M.E., Gomez-Guillen, M.C., \& Montero, P., (2015). Chitosan coatings enriched with active shrimp waste for shrimp preservation. Food Control, 54, 259-266.

Balfour, S. T., Badrie, N., Chang Yen, I., \& Chatergoon, L. (2014). Microbiological, physical and sensory quality of marine shrimp (Peneaus spp.) sold by vendors in Trinidad, West Indies. International Food Research Journal, 21(4), 1279-1288. 
Bono, G., \& Badalucco, C. (2012). Combining ozone and modified atmosphere packaging (MAP) to maximize shelf-life and quality of striped red mullet (Mullus surmuletus). LWT-Food Science and Technology, 47(2), 500-504.

Boonsumrej, S., Chaiwanichsiri, S., Tantratian, S., Suzuki, T., \& Takai, R. (2007). Effects of freezing and thawing on the quality changes of tiger shrimp (Penaeus monodon) frozen by air-blast and cryogenic freezing. Journal of Food Engineering, 80(1), 292-299.

Bindu, J., Ginson, J., Kamalakanth, C.K., Asha, K.K., \& Gopal, T.S. (2013). Physicochemical changes in high pressure treated Indian white prawn (Fenneropenaeus indicus) during chill storage. Innovative Food Science \& Emerging Technologies, 17, 37-42.

Caesarita, D.P., Suryaatmaja, L., \& Kristina, T.N. (2011). Pengaruh Ekstrak Buah Nanas (Ananas comosus) 100\% Terhadap Bakteri Staphylococcus Aureus Dari Pioderma. (Undergraduate Thesis), Universitas Diponegoro.

Chau, N.T.T., Quang, P.H., Lan, P.T.N., Matsumoto, M., \& Miyajima, I. (2011). Identification and Characterization of Pseudomonas sp. P 9 Antagonistic to Pathogenic Vibrio spp. Isolated from Shrimp Culture Pond in Thua Thien Hue-Viet Nam. Journal of the Faculty of Agriculture, Kyushu University, 56(1), 2331.

Chinese National Standard (GB4789.2-2010). (2010). Microbiological examination of food hygiene: Detection of aerobic bacterial count. Beijing: Chinese National Hygiene Ministry.

Fan,W., Sun, J., Chen, Y., Qiu, J., Zhang, Y., \& Chi, Y. (2009). Effects of chitosan coating on quality and shelf life of silver carp during frozen storage. Food Chemistry, 115(1), 66-70.
Farajzadeh, F., Motamedzadegan, A., Shahidi, S. A., \& Hamzeh, S. (2016). The effect of chitosan-gelatin coating on the quality of shrimp (Litopenaeus vannamei) under refrigerated condition. Food Control, 67, 163-170.

Ferreira, E. A., Siqueira, H. E., Boas, E. V. V., Hermes, V. S., \& Rios, A. D. O. (2016). Bioactive compounds and antioxidant activity of pineapple fruit of different 44 cultivars. Revista Brasileira de Fruticultura, $38(3)$.

Food and Agriculture Organization of the United Nations (FAO). (2010). Yearbook of fishery and aquaculture statistics 2008. Retrieved from http://www.fao.org/ docrep/013/ i1890t/i1890t.pdf, 1 October 2008.

Godiksen, H., Morzel, M., Hyldig, G., \& Jessen, F. (2009). Contribution of cathepsins B, L and D to muscle protein profiles correlated with texture in rainbow trout (Oncorhynchus mykiss). Food Chemistry, 113(4), 889-896.

Hsu, W. H., Tsai, H. Y., \& Huang, Y. C. (2017). Characteristics of carbon nanotubes/ graphene coatings on stainless steel meshes used as electrodes for air-cathode microbial fuel cells. Journal of Nanomaterials, 2017.

Huang, J., Chen, Q., Qiu, M., \& Li, S. 2012. Chitosan-based edible coatings for quality preservation of postharvest whiteleg shrimp (Litopenaeus vannamei). Journal of Food Science, 77(4), 491-C496.

Imran, A., Chawalit, J., \& Somrote, K. (2013). Characterization of quality degradation during chilled shrimp (Litopenaeus vannamei) supply chain. International Food Research Journal, 20(4), 1833-1842.

Jeon, Y.J., Kamil, J.Y. \& Shahidi, F. (2002). Chitosan as an edible invisible film for quality preservation of herring and Atlantic cod. Journal of Agricultural and Food Chemistry, 50(18), 5167-5178. 
Loon, Y.K., Satari, M.H., \& Dewi, W. (2018). Antibacterial effect of pineapple (Ananas comosus) extract towards Staphylococcus aureus. Padjadjaran Journal of Dentistry, 30(1), 1-6.

Martins, B. C., Rescolino, R., Coelho, D. F., Zanchetta, B., Tambourgi, E. B., \& Silveira, E. (2014). Characterization of bromelain from ananas comosus agroindustrial residues purified by ethanol factional precipitation. Chemical Engineering Transactions, 37, 781-786.

Maurer, H.R. (2001). Bromelain: biochemistry, pharmacology and medical use. Cellular and Molecular Life Sciences (CMLS), 58(9), 1234-1245.

Meinert, E.M., Beirão, L.H., \& Teixeira, E. (1999). Sensory and instrumental texture evaluation of restructured shrimp. British Food Journal, 101(11).

Mohan, C. O., Ravishankar, C. N., Lalitha, K. V., \& Gopal, T. S. (2012). Effect of chitosan edible coating on the quality of double filleted Indian oil sardine (Sardinella longiceps) during chilled storage. Food Hydrocolloids, 26(1), 167-174.

Montero, P., Lopez-Caballero, M.E., \& PérezMateos, M. (2001). The effect of inhibitors and high pressure treatment to prevent melanosis and microbial growth on chilled prawns (Penaeus japonicus). Journal of Food Science, 66(8), 1201-1206.

Soyoung Na, S., Kim, J-H., Jang, H-J., Park, H-J., \& Oh, S-W. (2018). Shelf life extension of Pacific white shrimp (Litopenaeus vannamei) using chitosan and $\varepsilon$-polylysine during cold storage. International Journal of Biological Macromolecules, 115, 11031108.

Nirmal, N. P., \& Benjakul, S. (2011). Retardation of quality changes of Pacific white shrimp by green tea extract treatment and modified atmosphere packaging during refrigerated storage. International Journal of Food Microbiology, 149, 247-253.
Rahman, M.S., Al-Amri, O.S., \& Al-Bulushi, I.M., (2002). Pores and physico-chemical characteristics of dried tuna produced by different methods of drying. Journal of Food Engineering, 53(4), 301-313.

Ruslan, N. A., Aris, N. F. M., Othman, N., Saili, A. R., Muhamad, M. Z., \& Aziz, N. N. H. (2017). A Preliminary Study on Sustainable Management of Pineapple Waste: Perspective of Smallholders. International Journal of Academic Research in Business and Social Sciences, 7(6), 1-7.

Saraswaty, V., Risdian, C., Primadona, I., Andriyani, R., Andayani, D. G. S., \& Mozef, T. (2017). Pineapple peel wastes as a potential source of antioxidant compounds. In IOP Conference Series: Earth and Environmental Science (Vol. 60(1), 012013). IOP Publishing.

Schieber, A., Stintzing, F.C., \& Carle, R. (2001). By-products of plant food processing as a source of functional compounds recent developments. Trends in Food Science \& Technology, 12, 401-413.

Soares, P. A., Vaz, A. F., Correia, M. T., Pessoa Jr, A., \& Carneiro-da-Cunha, M. G. (2012). Purification of bromelain from pineapple wastes by ethanol precipitation. Separation and Purification Technology, 98, 389-395.

Souza, B. W. S., Cerqueira, M. A., Martins, J. T., Casariego, A., Teixeira, J. A., \& Vicente, A. A. (2010). Influence of electric fields on the structure of chitosan edible coatings. Food Hydrocolloids, 24(4), 330-335.

Sriket, P., Benjakul, S., Visessanguan, W., \& Kijroongrojana, K. (2007). Comparative studies on chemical composition and thermal properties of black tiger shrimp (Penaeus monodon) and white shrimp (Penaeus vannamei) meats. Food Chemistry, 103(4), 1199-1207.

Sun, H. Y., L, H., Yuan, G. F., \& Fang, X. B. (2014). Effect of grape seed extracts on the melanosis and quality of Pacific white shrimp (Litopenaeus vannamei) during iced storage. Food Science and Technology Research, 20(3), 671-677. 
Yuan, G., Lv, H., Tang, W., Zhang, X. \& Sun, H. Zharfan, R.S., Purwono, P.B., \& Mustika, A. (2016). Effect of chitosan coating combined with pomegranate peel extract on the quality of pacific white shrimp during iced storage. Food Control, 59, 818-823.

Zayed, M. Z., Ahmad, F. B., Ho, W. S., \& Pang, S. L. (2014). GC-MS analysis of (2017). Antimicrobial activity of pineapple (Ananas comosus L. Merr) extract against multidrug-resistant of Pseudomonas aeruginosa: an in vitro study. Indonesian Journal of Tropical and Infectious Disease, phytochemical constituents in leaf extracts of Neolamarckia cadamba (Rubiaceae) from Malaysia. International Journal of Pharmacy and Pharmaceutical Sciences, 6(9), 123-127. 6(5), 118-123. 
